\title{
IMPLEMENTASI SMS GATEWAY SEBAGAI SISTEM INFORMASI KEUANGAN SISWA (STUDI KASUS : SMP NEGERI 6 SINGINGI HILIR)
}

\author{
Dewi Laraswati ${ }^{1)}$, Elgamar Syam ${ }^{2)}$ \\ ${ }^{1}$ Program Studi Teknik Informatika, Fakultas Teknik, Universitas Islam Kuantan Singingi \\ J1. Gatot Subroto Km. 7 Jake, Teluk Kuantan \\ E-mail: dewilaraswati17@gmail.com \\ ${ }^{2}$ Program Studi Teknik Informatika, Fakultas Teknik, Universitas Islam Kuantan Singingi \\ Jl. Gatot Subroto Km. 7 Jake, Teluk Kuantan \\ E-mail : elgamar@uniks.ac.id
}

\begin{abstract}
The school is one of the many sectors that have experience the development of information technology. Because one of the conditions for raising grades in certain schools is technology based facilities. In this case, SMPN 6 Singingi Hilir require a financial information system that can process student payments, convey information about student finances and can process reports. To overcome these problems need to be made a computerized information system. The research method used is the method of data collection by means of interviews and observations. While the system development methodology uses SDLC (System Development Life Cycle). Analysis and design tools used are structured data, like use case diagram, sequence diagram, Activity diagram and class diagram. The appilication program used is Java Netbeans IDE and database used is MySQL. The research is expected to produce a financial information system for students who can help optimally.
\end{abstract}

Keyword : Information System, Payment, SMS Gateway

\begin{abstract}
ABSTRAK
Sekolah adalah salah satu dari sekian banyak sektor yang telah merasakan perkembangan teknologi informasi. Karena salah satu syarat untuk menaikkan grade pada sekolah tertentu ialah adanya sarana berbasis teknologi. Dalam hal ini, SMPN 6 Singingi Hilir membutuhkan sistem informasi keuangan yang dapat mengolah pembayaran siswa, menyampaikan informasi seputar keuangan siswa serta dapat mengolah laporan. Untuk mengatasi masalah tersebut perlu dibuat suatu sistem informasi yang terkomputerisasi. Metode penelitian yang digunakan yaitu metode pengumpulan data dengan cara wawancara dan observasi. Sedangkan metodologi pengembangan sistemnya menggunakan SDLC (System Development Life Cycle). Alat bantu analisis dan perancangan yang digunakan adalah data terstruktur, diantaranya use case diagram, sequence diagram, activity diagram, dan class diagram. Program aplikasi yang digunakan adalah Java Netbeans IDE serta database menggunakan MySQL. Dari penelitian tersebut diharapkan dapat menghasilkan sistem informasi keuangan siswa yang dapat membantu secara maksimal.
\end{abstract}

Kata kunci : Sistem Informasi, Keuangan, SMS Gateway. 


\section{PENDAHULUAN}

Di era globalisasi, perkembangan teknologi informasi berkembang dengan sangat pesat, merambat ke berbagai sektor yang salah satunya dibidang pendidikan. Sering sekali orang menginginkan tantangan kecepatan, ketepatan, dan kemudahan didalam akses suatu sistem informasi yang harus dapat dipenuhi dengan baik. Hal tersebut tidak lepas dari peran sumber daya manusia yang mampu mengembangkan dan memanfaatkan perkembangan teknologi informasi untuk berbagai kepentingan.

Sekolah menjadi salah satu dari sekian banyak sektor yang telah merasakan perkembangan teknologi informasi. Karena salah satu syarat untuk menaikkan grade pada sekolah tertentu ialah adanya sarana berbasis teknologi. Teknologi begitu banyak memudahkan pekerjaan-pekerjan pada sekolah-sekolah, salah satunya di bagian keuangan. Dimana di bagian ini, beberapa pekerjaan membutuhkan kecepatan teknologi, ketepatan, dan kecepatan informasi. Para staf di bagian keuangan membutuhkan komputer guna mengolah laporan keuangan, membutuhkan internet guna menyebarkan informasi seputar laporan keuangan kepada wali murid, dan lain-lain yang berhubungan dengan teknologi informasi.

Seperti halnya pada Sekolah Menengah Pertama Negeri (SMPN) 6 Singingi Hilir yang terletak di Kecamatan Singingi Hilir Kabupaten Kuantan Singingi, dimana sekolah ini sangat membutuhkan bantuan teknologi guna mengolah data keuangan siswa. Dengan semakin bertambahnya siswa, maka pencatatan administrasi keuangan yang sebelumnya dilakukan secara manual semakin tidak efisien dikarenakan penyimpanan dan pencatatan data-data akan rawan terjadi kerusakan dan kehilangan data-data. Selain masalah tersebut, juga terdapat masalah lagi yang utama yaitu penyampaian informasi keuangan siswa yang masih konvensional.

Konvensional disini ialah masih menggunakan metode surat (kertas) yang diberikan kepada wali murid melalui siswa. Cara ini tidak efektif karena kadang surat yang diberikan tidak sampai kepada wali murid dan juga membutuhkan waktu yang lama, dan terkadang uang yang diberikan orang tua untuk pembayaran sekolah disalahgunakan atau tidak dibayarkan oleh siswa sehingga menimbulkan kesulitan bagi pihak orang tua dan sekolah ketika terjadi tunggakan di akhir tahun. Penerapan SMS Gateway kedalam pelayanan publik mampu menjadi solusi dan nilai tambah dalam meningkatkan kualitas administrasi dan informasi keuangan.

Pada prinsipnya, SMS gateway adalah sebuah perangkat lunak yang memanfaatkan komputer dan teknologi seluler yang kemudian diintegrasikan untuk mendistribusikan pesanpesan yang diturunkan melalui sistem informasi menggunakan SMS. Kelebihan SMS gateway adalah aplikasinya berbasis komputer sehingga dapat dijalankan dan dapat menyimpan data dalam jumlah banyak karena disimpan dalam sebuah hardisk server (Sihotang, F. P., \& Jumeilah, F. S : 2017).

Dari permasalahan diatas, maka penulis menyarankan perlunya penerapan sistem informasi keuangan siswa, yang penulis beri judul "Implementasi SMS Gateway sebagai Sistem Informasi Keuangan Siswa". Sistem ini membantu bagian keuangan dalam mengirimkan informasi seputar transaksi pembayaran yang dilakukan siswa kepada orang tua. 
Hal : $65-73$

\section{TINJAUAN PUSTAKA}

\subsection{SMS Gateway}

Short Message Service (SMS) memiliki kemampuan untuk mengirim dan menerima pesan dalam bentuk teks dari dan kepada ponsel, teks tersebut bisa terdiri dari huruf, angka atau kombinasi alphanumeric (Afrina, M., \& Ibrahim, A : 2015).

SMS gateway menjadi pintu gerbang dalam penyebaran informasi menggunakan SMS, proses penyebaran informasi atau meminta informasi dilakukan melalui server SMS tersebut, SMS gateway mampu mengcustomisasi keyword dan informasi apa saja yang akan dikirimkan (Suryana, T, 2012).

Disebut pesan teks karena pesan yang dikirimkan hanya berupa karakter teks yang panjangnya tidak lebih dari 160 karakter. Awalnya, SMS dirancang sebagai bagian dari jaringan GSM (Global Standard for Mobiles). Namun sekarang hal tersebut telah berkembang ke jaringan bergerak lainnya, antara lain TDMA (Time Division Multiple Access) dan CDMA (Code Division Multiple Acces).

\subsection{Sistem Informasi}

Sistem merupakan suatu bentuk integrasi antara satu komponen dengan komponen lain karena sistem memiliki sasaran yang berbeda untuk setiap kasus yang terjadi di dalam sistem tersebut (Sutabri, T. 15: 2012).

Informasi adalah data yang telah diolah menjadi bentuk yang lebih berguna bagi yang menerima (Sihotang, H. T. : 2018).

Sistem Informasi adalah kumpulan elemen yang saling berhubungan satu sama lain yang membentuk satu kesatuan untuk mengintegrasikan data, memproses dan menyimpan serta mendistribusikan informasi (Sihotang, H. T. : 2018).

\subsection{Gammu}

Gammu merupakan sebuah aplikasi yang dapat digunakan untuk mengelola berbagai fungsi pada handphone, modem, dan perangkat sejenis lainnya (Masruri, M. H., \& Creativity, J. : 2015).

Gammu merupakan penghubung (gateway) yang menghubungkan perangkat komputer dengan perangkat handphone atau modem, pada penggunaan khusus gammu dapat digunakan sebagai sms gateway (Sardiarinto : 2014).

\section{METODE PENELITIAN}

Proses penelitian dimulai dari identifikasi masalah, dimana peneliti berupaya merangkum segala permasalahan yang timbul disebabkan model sistem yang lama, kemudian proses analisa kebutuhan menjadi tolok ukur dalam perancangan dan pembuatan sistem yang baru. Selanjutnya kegiatan pengumpulan data dilakukan guna mempersiapkan bahan dalam proses implementasi penelitian, kemudian barulah melakukan perancangan sesuai kebutuhan sistem dan dilakukan implementasi sistem. Pengujian sistem dan evaluasi sistem menjadi syarat agar sistem yang dibangun berjalan sesuai dengan yang diharapakan. Berikut gambaran flowchart penelitian dari awal sampai selesai: 
VOL. 2 No. 1, Juni 2019

Hal : $65-73$

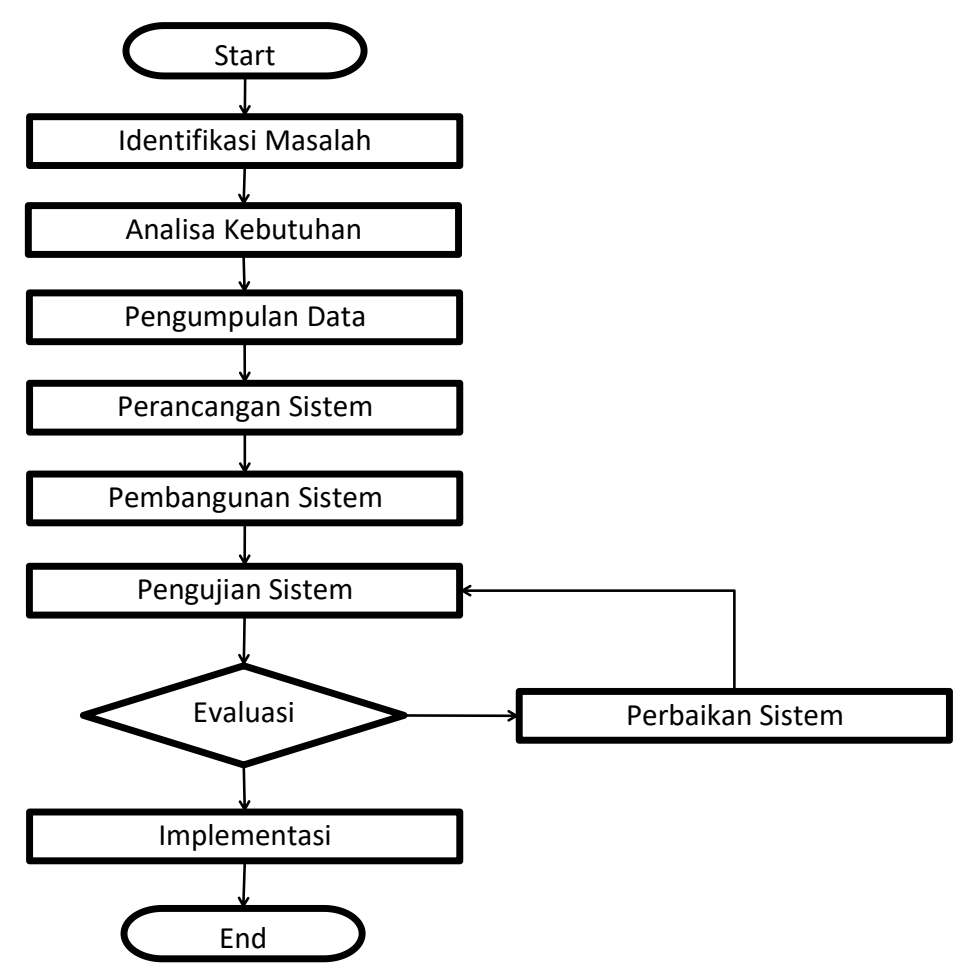

Gambar 1. Flowchart Penelitian

\subsection{Software dan Hardware}

Perangkat yang digunakan untuk mendukung kegiatan pembangunan sistem terdiri dari perangkat lunak dan perangkat keras.

\subsubsection{Perangkat Lunak}

1. Java NetBeans IDE, yang berguna sebagai aplikasi editor pemrograman bahasa Java.

2. MySQL, sebagai pusat data (database).

3. Gammu, sebagai perangkat lunak yang berfungsi untuk menghubungkan modem ke komputer.

\subsubsection{Perangkat Keras}

1. Laptop ASUS A456U.

2. CPU "Intel Core I5-6200U".

3. Memory RAM 4GB

4. Modem Huawei dan kartu GSM (telkomsel dan xl). Modem berfungsi sebagai perangkat SMS Gateway dalam membalas dan memberikan respon otomatis terhadap request SMS yang dikirim dari pengguna.

\section{HASIL DAN PEMBAHASAN}

\subsection{Analisa Sistem yang Sedang Berjalan}

Setelah dilakukan wawancara dan observasi penelitian, maka diketahui sistem keuangan SMPN 6 Singingi Hilir yang sedang berjalan belum memanfaatkan teknologi sepenuhnya. 
VOL. 2 No. 1, Juni 2019

Hal : $65-73$

\subsection{Analisa Sistem Yang Diusulkan}

Berdasarkan analisa sistem yang sedang berjalan, maka diperlukan sebuah sistem yang dapat memberikan informasi secara akurat kepada pengguna (wali murid) serta memudahkan admin (pegawai keuangan) dalam pembuatan laporan dengan memanfaatkan fasilitas SMS Gateway.

\subsubsection{Use Case Diagram}

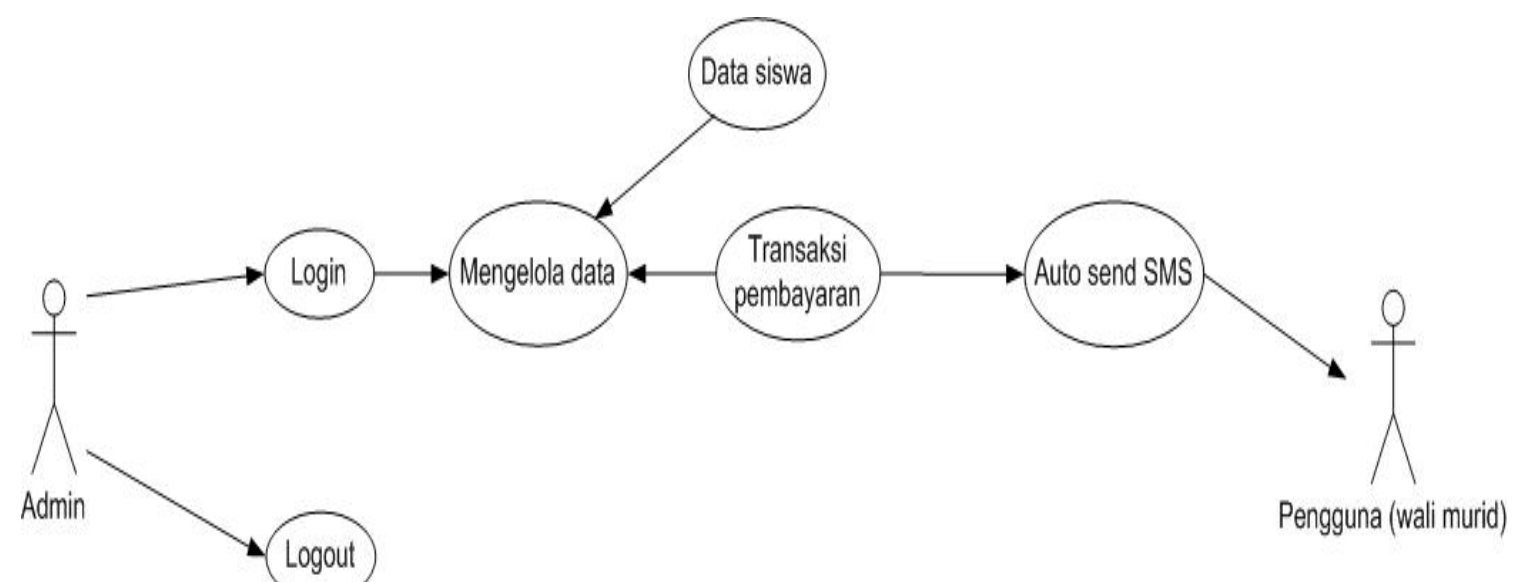

Gambar 2. Use Case Diagram

\subsubsection{Sequence Diagram}

a. Sequence diagram proses login

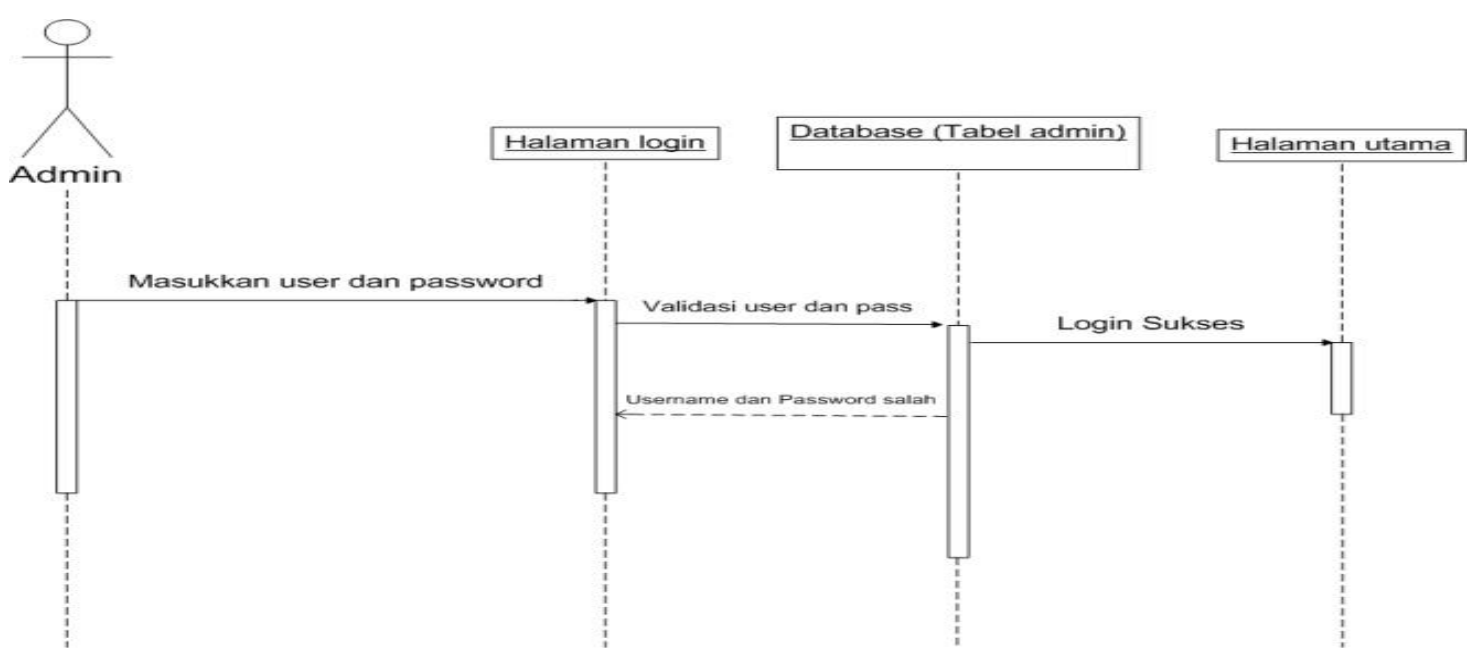

Gambar 3. Sequence Diagram Login 
VOL. 2 No. 1, Juni 2019

Hal : $65-73$

\section{b. Sequence diagram mengelola data siswa}

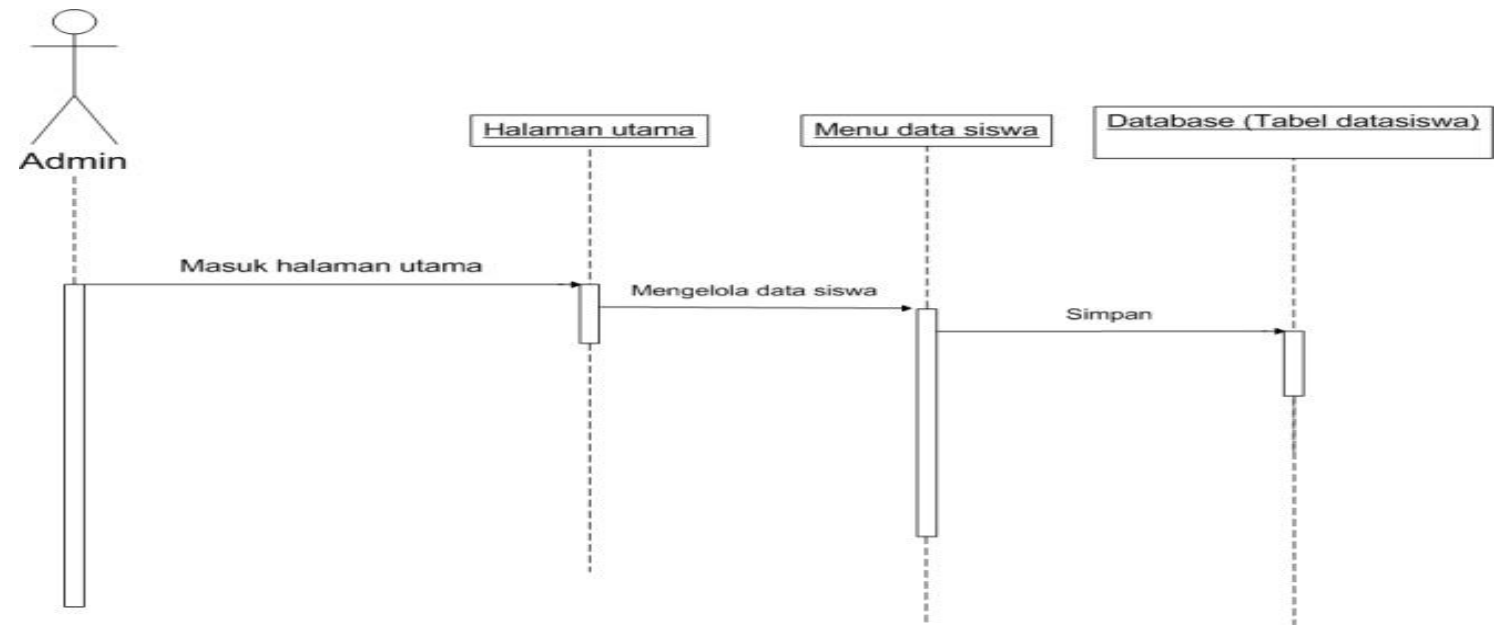

Gambar 4. Sequence Diagram Kelola data siswa

c. Sequence diaram mengelola transaksi pembayaran

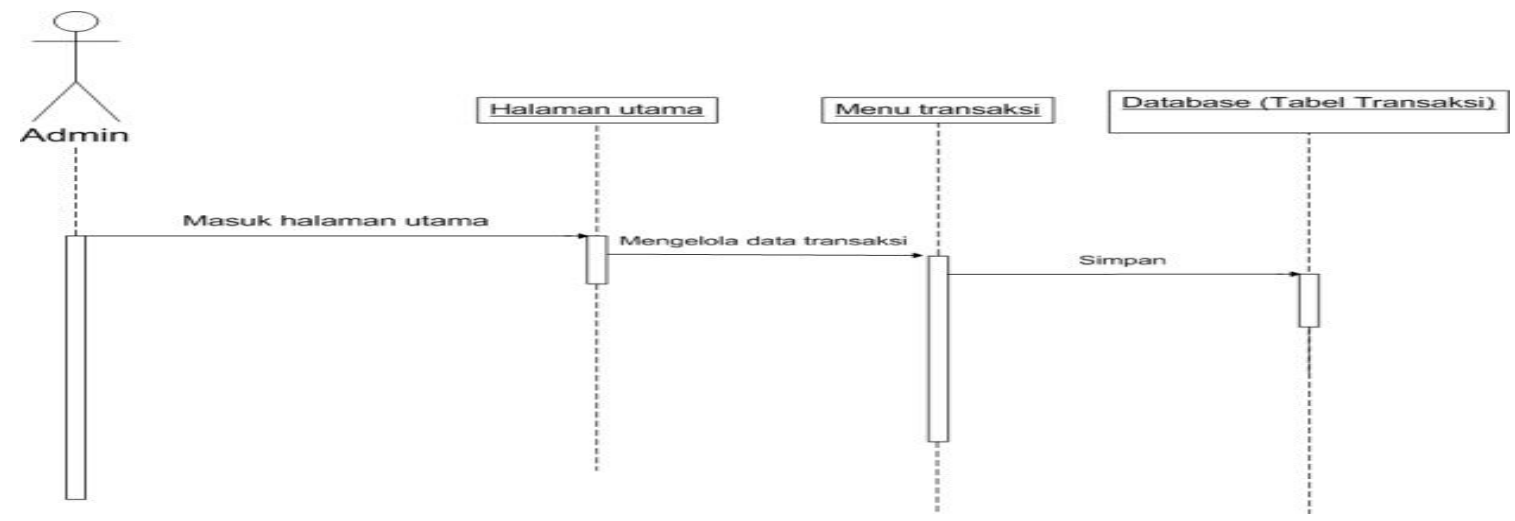

Gambar 5. Sequence Diagram Transaksi Pembayaran

\subsubsection{Class Diagram}

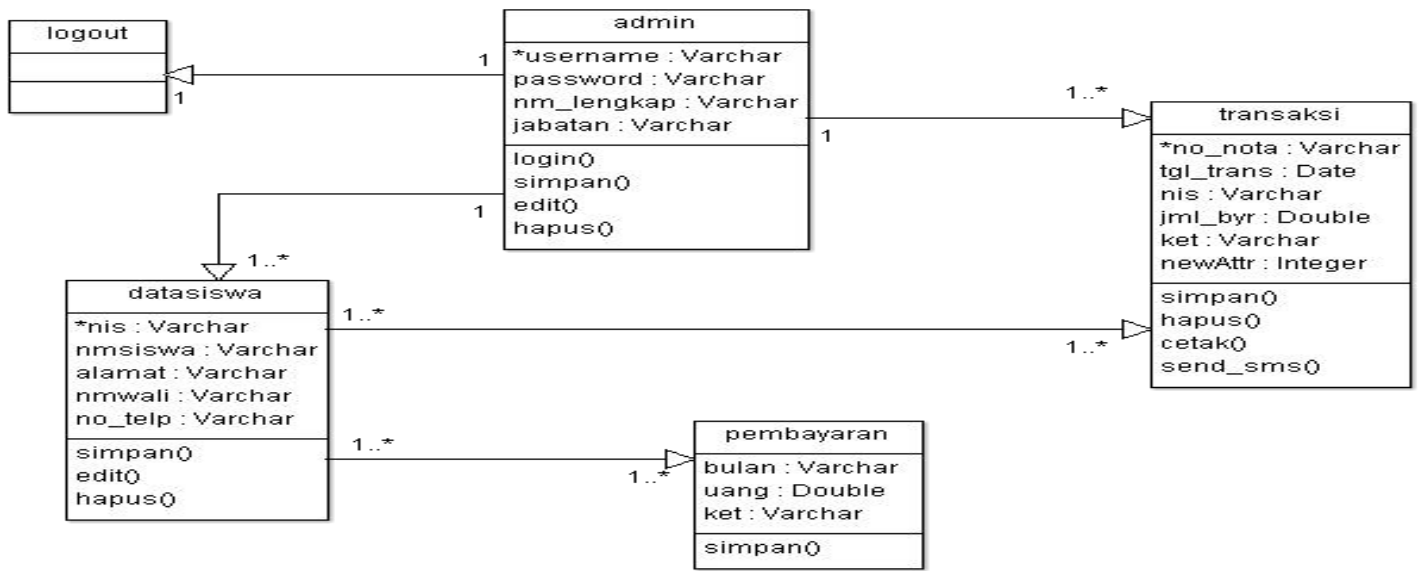

Gambar 6. Class Diagram 
VOL. 2 No. 1, Juni 2019

$\mathrm{Hal}: 65-73$

\subsubsection{Activity Diagram}

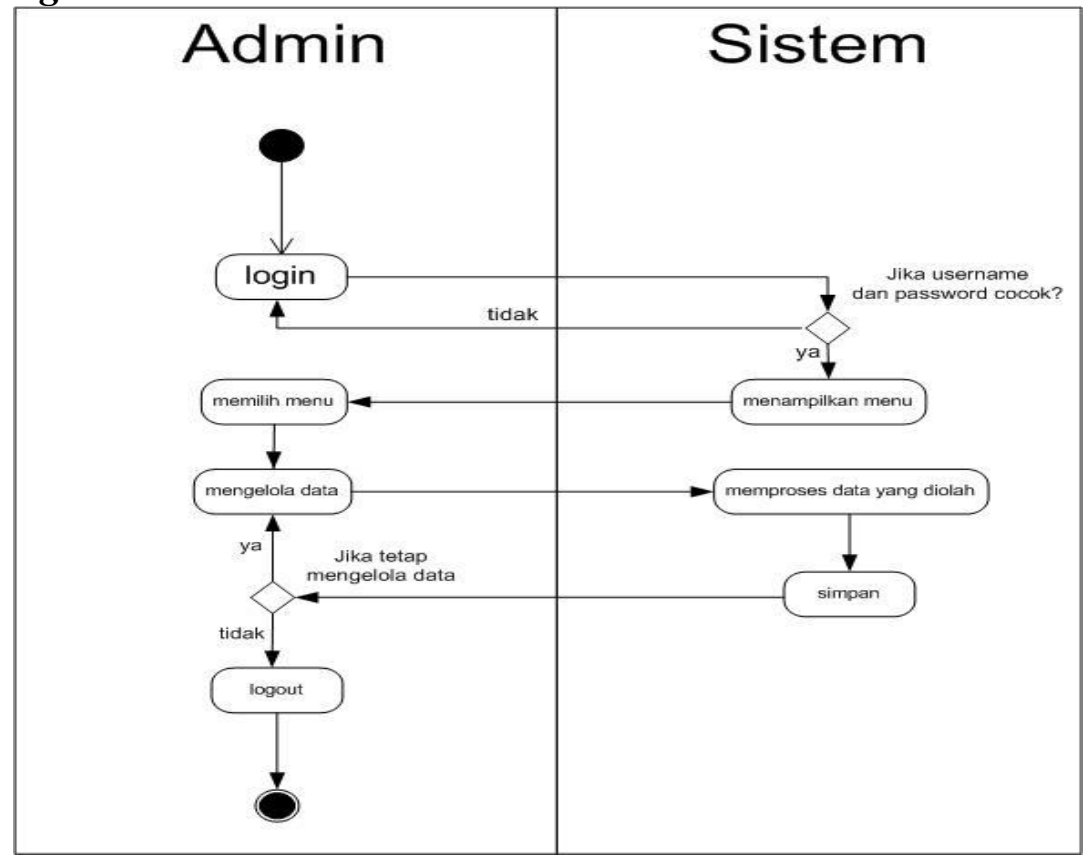

Gambar 7. ActivityDiagram

\subsection{Pengujian dan Implementasi Sistem}

Pada sistem yang telah jadi, sehingga dapat diimplementasikan dengan tampilan sistem seperti di bawah ini :

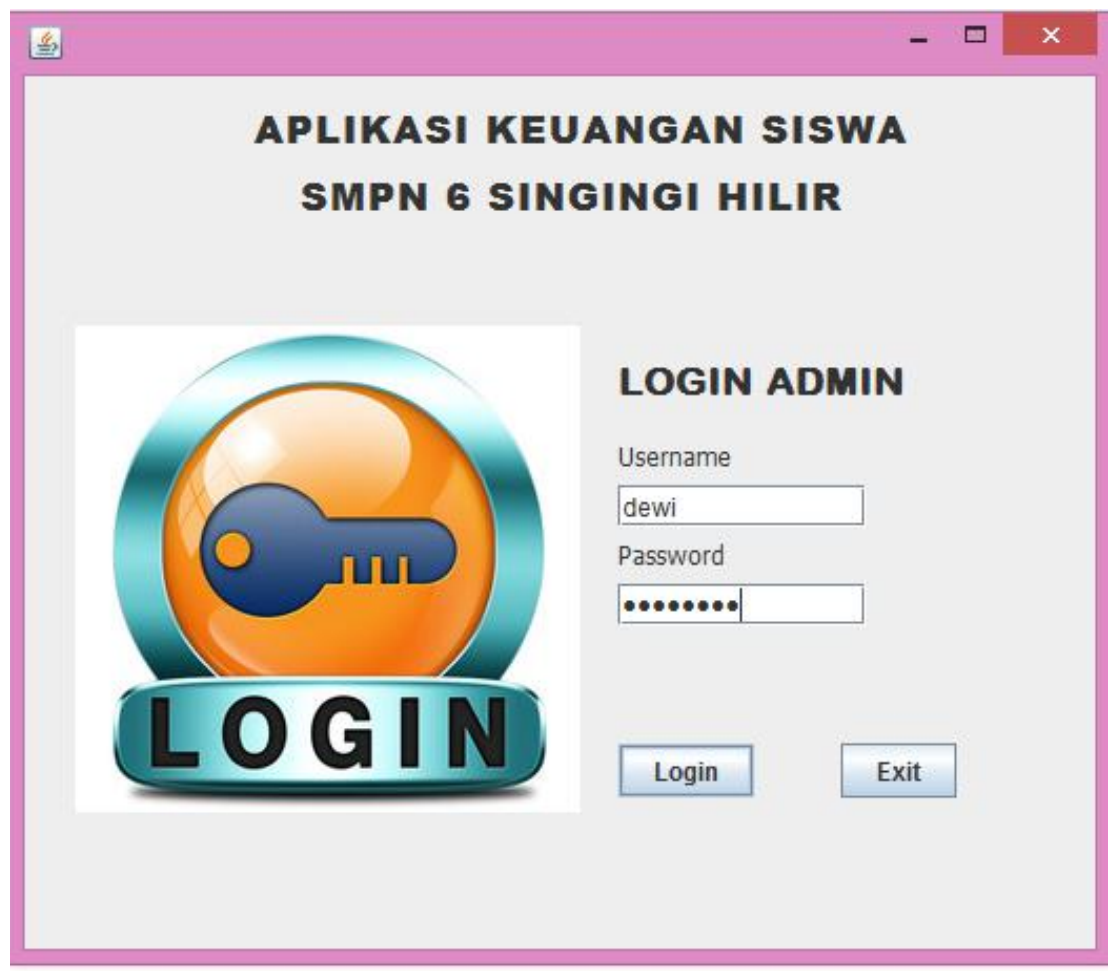

Gambar 8. Menu Login 
VOL. 2 No. 1, Juni 2019

Hal : $65-73$

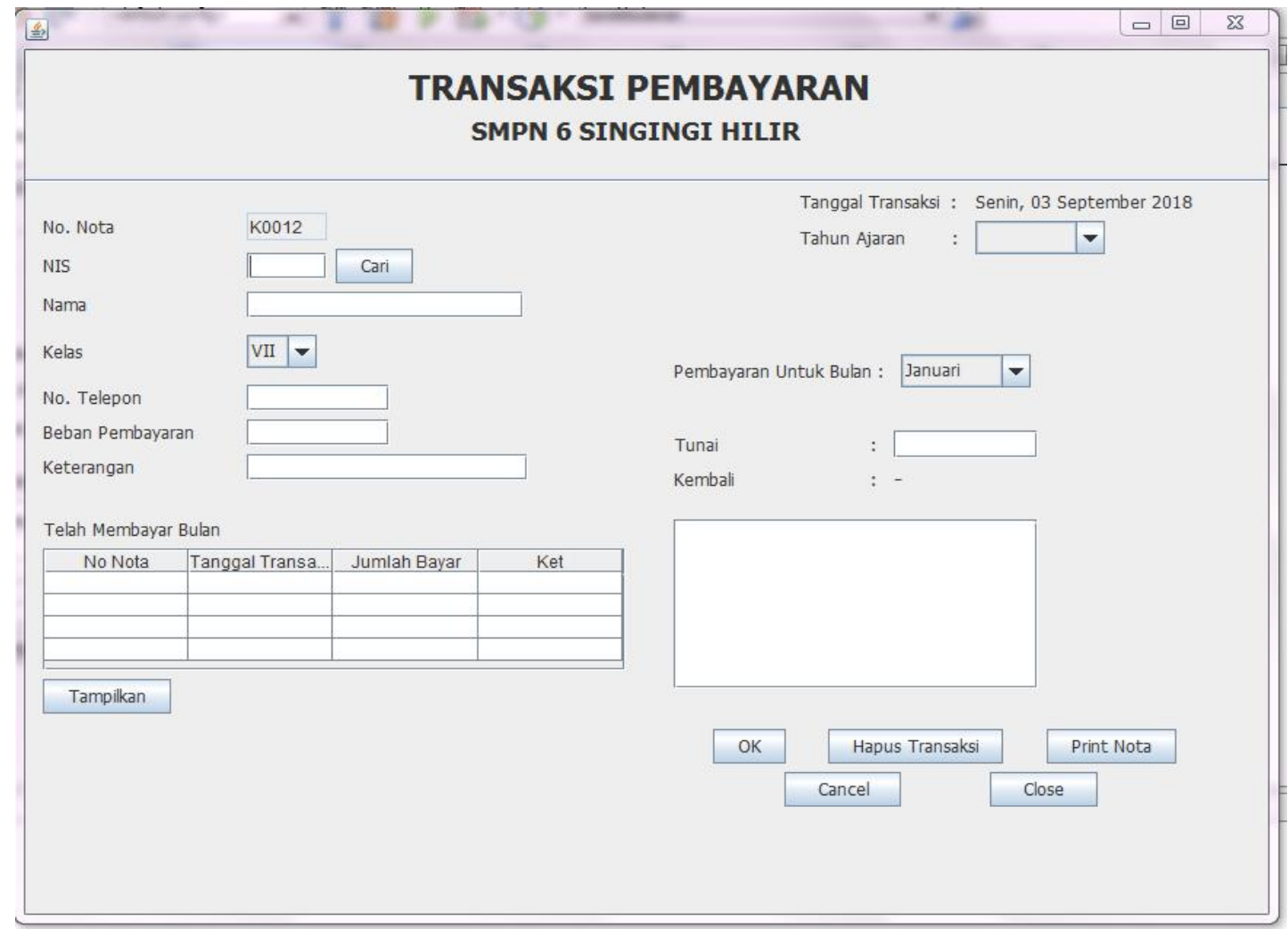

Gambar 9. Menu Transaksi

Setelah siswa melakukan pembayaran, sistem melakukan record dan melakukan pengiriman SMS secara otomatis (auto reply) kepada wali murid sipenerima SMS yang sebelumnya nomor seluler penerima telah diinputkan kedalam sistem. SMS yang diterima berupa pemberitahuan kepada wali murid bahwa siswa tersebut telah melakukan pembayaran dengan jumlah yang telah ditentukan.

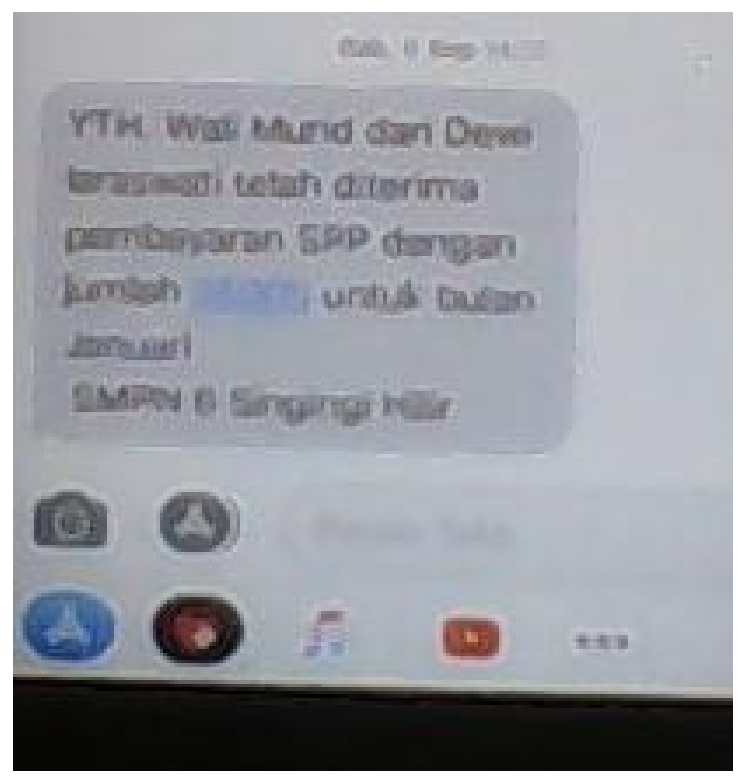

Gambar 10. Menu Transaksi 
Hal : $65-73$

\section{SIMPULAN}

Berdasarkan hasil penelitian dan pembahasan yang dilakukan pada Implementasi SMS Gateway sebagai Sistem Informasi Keuangan Siswa maka dapat disimpulkan bahwa :

1. Sistem dapat membantu dan mempermudah penyampaian informasi seputar keuangan siswa di SMPN 6 Singingi Hilir dengan memanfaatkan fasilitas sms gateway secara cepat dan praktis, sehingga orang tua dapat lebih cepat mengetahui informasinya.

2. Masalah petugas keuangan dalam hal membuat laporan bulanan dapat teratasi dengan sistem ini.

3. Pengembangan perangkat lunak sistem informasi keuangan siswa dilakukan dengan menggunakan Java Netbeans IDE. Fitur SMS Gateway menggunakan Gammu sebagai Engine-nya. Dalam penelitian ini, perangkat lunak dikembangkan untuk membantu pelayanan administrasi pembayaran sekolah meliputi pengelolaan data dan penyedia informasi.

\section{DAFTAR PUSTAKA}

Abidin, R., \& Kuncoro, A. A. (2015). Aplikasi Pembayaran SPP di Lingkungan Yayasan AzZahra Demak Berbasis Client Server Terintegrasi dengan SMS Gateway. JURNAL ELEKTRONIKA DAN KOMPUTER, 8(1).

Afrina, M., \& Ibrahim, A. (2015). Pengembangan Sistem Informasi SMS Gateway Dalam Meningkatkan Layanan Komunikasi Sekitar Akademika Fakultas Ilmu Komputer Unsri. Jurnal Sistem Informasi, 7(2).

Gede, M. I. (2015). Perancangan SMS Gateway untuk Sistem Informasi Manajemen Keuangan STMIK STIKOM Bali. Proceedings Konferensi Nasional Sistem dan Informatika (KNS\&I).

Haviluddin, H. (2016). Memahami Penggunaan UML (Unified Modelling Language). Informatika Mulawarman: Jurnal Ilmiah Ilmu Komputer, 6(1), 1-15.

Masruri, M. H., \& Creativity, J. (2015). Membangun SMS Gateway dengan Gammu \& Kalkun. Elex Media Komputindo.

Sardiarinto, S. (2014). APLIKASI SMS GATEWAY UNTUK KEAMANAN SISTEM INFORMASI BERBASIS WEB. Bianglala Informatika, 2(1).

Shodikun, A., \& Syam, E. (2018). PEMBANGUNAN SMS GATEWAY HASIL PEMERIKSAAN UJIAN SEKOLAH BERBASIS WEB PADA MA BAHRUL ULUM SINGINGI. JURNAL TEKNOLOGI DAN OPEN SOURCE, 1(2), 1-12.

Sihotang, F. P., \& Jumeilah, F. S. (2017). Pengembangan SMS Gateway Layanan Informasi Akademik di STMIK GI MDP. Jurnal Rekayasa Sistem dan Teknologi Informasi, 1(1).

Sihotang, H. T. (2018). Sistem Informasi Pengagendaan Surat Berbasis Web Pada Pengadilan Tinggi Medan. Journal Of Informatic Pelita Nusantara, 3(1).

Supriyono, H., Saputro, N. A., \& Pradessya, R. A. (2016). Rancang Bangun Sistem Informasi Manajemen Presensi Berbasis SMS Gateway (Studi Kasus: SMP Muhammadiyah 1 Kartasura).

Suryana, T., \& Indonesia, I. K. U. K. (2012). SMS Gateway Kannel Sebagai Sarana Penunjang Informasi Akademik. Jurnal Ilmiah Komputer dan Informatika (KOMPUTA), 1(2), 17-30.

Sutabri, T. (2012). Analisis sistem informasi. Penerbit Andi. 